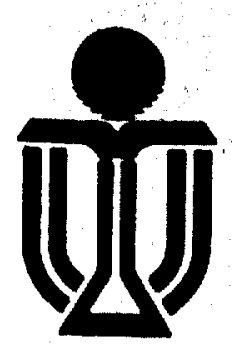

Division of Social Science

The Hong Kong University of Science and Technology

Working Papers in the Social Sciences, No. 32

\title{
Preferential Policies for Ethnic Minorities in China: The Case of Xinjiang
}

by

Barry Sautman

Division of Social Science

Hong Kong University of Science and Technology

Clear Water Bay

Kowloon, Hong Kong

30 September 1997 


\title{
PREFERENTIAL POLICIES FOR ETHNIC MINORITIES IN CHINA: THE CASE OF XINJIANG
}

\author{
Barry Sautman \\ Division of Social Science \\ Hong Kong University of Science \& Technology \\ Clearwater Bay, Kowloon, Hong Kong \\ T: 852 2358-7821; F: 852 2335-0014 \\ E: sobarryseusthk.ust.hk \\ Draft of 30 September 1997
}




\section{Preferential Policies for Ethnic Minorities in China: \\ the Case of Xinjiang}

Heated debates rage in several countries about the propriety and efficacy of government programs of special benefits for ethnic minorities with a history of political and economic subordination. "Affirmative action" in the United States, Canada, Australia and South Africa, "positive discrimination" in Britain and "reservations" in India have engendered many scholarly studies. Those that use a comparative perspective include books (Nesiah, 1997; Parikh, 1997; Kumar, 1991; Sowell, 1990; Wyzan, 1990), monographs (Faundez, 1994; Centre for Development Studies, 1992; Killian, 1981), conference proceedings (Rockefeller Foundation, 1984; Weiner, 1993); articles (de Vries \& Pettigrew, 1994; Weiner, 1983) and theses (Ahmed, 1992; Ng, 1991).

None of these works consider what may be the most important case. China's preferential policies (youhui zhengce) embrace minority peoples who, in 1995, at nine percent of the population, were 110 million, a figure up 20 million in just five years and 40 million less than the number expected in 2010 (Xinhua, February 14, 1996; Hasi Bagen, 1995). The popular aphorism of China as "di da w'u bo" (a large territory and abundartt resources) owes to the size (two-thirds of the PRC's territory) and natural wealth of its minority regions (Jiao Shuqian, 1996). China's preferences, moreover, are broader (encompassing a wider array), deeper (affecting almost all minority people) and more variegated (due 
to decentralization) than those of most other countries.

China's preferential policies thus effect national unity, but the effect is paradoxically both profound and shallow: profound in that preferential policies are a key legitimating strategy of a regime which is overwhelmingly Han Chinese and claims that Han culture is more "advanced" than minority cultures; shallow in that the ethnic tensions and crises of confidence and competence for minorities that some scholars see as universal concomitants of preferential policies have yet to occur in China.

This essay will describe the scope of preferences in China, with particular reference to the Xinjiang Uygur Autonomous Region in China's northwest. Xinjiang borders eight countries and accounts for one-sixth of China's territory and 10.5 percent of her minority people. At the end of 1996 , the region had a population of 16.9 million of whom 10.5 million or 61.9 percent were minority people, a proportion officially unchanged since the national census of 1990 . Its importance to the integrity of the PRC is recognized by the regime to the extent of subsidizing some 50 percent of the Xinjiang's annual budget (Xinhua, March 14, 1997; Zhongguo minzu tongji nianjian, 1994:158; Li Fang, 1993:17). The essay will also discuss how preferential policies impinge on Han-minority relations. The question of tensions that are supposed to flow from affirmative action will be addressed and a few words will be said about how the Chinese case may inform the international debate about affirmative action. 


\section{I: The Dimensions of Affirmative Action in China}

Relations among China's 56 state-designated ethnic groups are officially described as "relations among the working people" (laodong renminde guanxi) that are "fairly good" or "on the whole quite good" (Mao Gongning, 1992; Agence France Presse (AFP), January 3, 1996; Dreyer, 1993:260). Deng Xiaoping boldfacedly claimed that "there has never been any ethnic discrimination" in China. Such ethnic frictions as exist are supposedly caused by "foreign instigation" or "a handful of splittists" (Xinhua, June 29, 1987; Zhang Lifang, 1994:10).

Chinese leaders do recognize, however, a need to reinforce the legitimacy of the regime among minorities (Gladney, 1995:262), most of whom live in areas markedly poorer than those inhabited by Han. Of 311 poor counties listed by the PRC State Council, 143 are in minority areas. More than 80 percent of Chinese who lack sufficient food and clothing live in minority areas (Xinhua, January 14, 1996; Lu Hui, 1992:3). PRC leaders hold that ethnic unity can be stabilized only when the standard of living in minority areas is greatly improved (Wu Zongjing, 1992:14; Davis, 1997:10). To that end, Article 122 of the PRC Constitution proclaims that "the state gives financial, material and technical assistance to the minority nationalities to accelerate their economic and cultural development" (Xinhua, December 4, 1982).

Since the mid-1980s, preferential policies have been touted as a way to narrow 
China's ethnic gap in living standards and education and reduce tensions through redistributive justice (Postiglione, 1992:24, 28; Barnett, 1993:141, 145, 248, 484, 645). Officials re-affirm that these policies will be employed for a long time to come (Amat, 1994). It is argued that if equal treatment were the basis, for example, of determining entry into universities, equality of opportunity would decline ( $\mathrm{Li} \mathrm{Zi}, 1995)$. The ultimate aim is "equality-in-fact" (shishishangde pingdeng) among ethnic groups (Chen Kuiyuan, 1991; Zhao Shu, 1995). For example, it has been stated that "the proportion of nationality cadres in the total number of cadres [should] match the ratio of the population of minority nationalities to the total population of the autonomous locality" (Jiang Ping and Huang Zhu, 1982).

At the same time, preferential policies are enmeshed in paternalistic notions that arise from the social evolutionism that pervades elite thinking about Hanminority relations (see Harrell, 1993:112). Thus, an eminent specialist of minority affairs has proclaimed that "the Han nationality has always kept a higher level of development, so many of the ethnic minorities have learned a lot from the Han nationality's mode of production and way of life" (Qiu Pu, 1989:34). Another has put it that

[T] he government has adopted various measures according to the special needs of each minority ... [T] [Te great assistance of the relatively more advanced Han is extremely important in speeding up the development of minorities. Yet the Han have selflessly regarded this kind of assistance as their responsibility (He Jiangcheng, 1990). 
Despite the tinge of mission civilatrice, preferential policies include benefits that sustain traditional minority lifestyles. For example, the 156 ethnic minority "autonomous areas" (five regions, 30 prefectures and 121 counties) can proclaim holidays for traditional festivities (Regulations, 1993). Even in cities outside the autonomies, minorities are entitled to leave at full pay to attend their festivities (Xinjiang TV, May 10, 1994). Special meals must be provided at work to Muslims and articles needed by minorities were, until recently, produced by state enterprises for sale at subsidized prices (Ma Yin, 1989:27-28; He, 1990:6; Xinhua, April 25, 1990; Gladney, 1991:187, 191). It is liberalized family planning, however, that is far and away the lifestyle benefit most sought-after by China's minorities.

\section{A: Farnily Planning Preferences}

From its inception, the PRC has accorded more liberal treatment to minorities in regard to marriage and childbirth. The Marriage Law of 1950 allowed polygamy and traditional divorce law in Muslim areas and Tibet (Lo, 1961:101; Feigon, 1995:151). Minorities today generally have the right to marry two years earlier than the minimum age for Han, i.e. at twenty for males and eighteen for females. The autonomies may issue their own legislation allowing marriage at an even younger age for minorities living in poor and remote areas and Xinjiang has done so (Hua Juxian, 1992; Xinhua, January 1, 1981; May 12, 1991). The average marriage age of Uygur women in two Xinjiang counties who married 
in 1984 was seventeen. While differences have narrowed, the marriage age of Xinjiang minority women is still well below that of Xinjiang Han. (Zhang Tianlu, 1990; Zhang Xia, 1994).

More important than the lower marriage age is the larger number of children allowed to minorities. From 1973, Han were limited to two and in the 1970s fertility fell by half. Based on the view of Mao Zedong that minorities prefer more children, they were exempted from these strictures (Hsieh, 1994:6; Conly \& Camp, 1992:7-8, 11; Banister \& Harbaugh, 1994:7; Chen, 1989; Zhang Tianlu, 1991:21). After a one-child policy was adopted in 1980, the state began to promote family planning in densely-populated minority areas (Xinhua, October 27,1982$)$, under the proclaimed principles that family planning should be conducive to "modernization," acceptable to minorities and helpful in strengthening minority-government ties (Luo Cun, 1997:52).

Mandatory family planning began among Xinjiang Han from 1975, but it was left to the discretion of minorities whether to practice it (Yuan Xin, 1994:14). Xianjiang's 1981 "Provisional Regulations on Issues of Family Planning Work" subjected only Han to regulation (Anderson \& Silver, 1995:214). In 1983, however, the regional People's Congress adopted a policy that permitted urban minorities only two children, unless both were girls or one was handicapped. Rural couples were allowed three children or a fourth if they lived in a remote locality (Xinhua, July 24, 1985). These restrictions led to a "riot" in Xinjiang's 
capital, Urumqi. Discontent continued after the enactment of the 1984 Law on Regional Autonomy (LRA; minzu quyu zizhi fa), Article 44 of which permits autonomies to adopt family planning measures that diverge from central government policies. Demonstrations were staged by Uygur students in Beijing and Shanghai in 1985 (Fraser, 1986).

A relaxation began thereafter for Xinjiang minorities, who were allowed as many as four children (Dixit. 1990). Meanwhile Beijing issued a 1986 directive that specified that most minorities were allowed two children in the cities and three in the countryside (Xinhua, December 4, 1986) and a 1988 regulation under which minorities should be limited to two children (Hsieh, 1994:6). In Xinjiang, however, a compromise was required. Under the 1988 "Temporary Regulations for Family Planning," most urban minority couples were allowed two children in cities and three children in towns. In special cases, however, a fourth child was permitted. Couples belonging to minorities with less than 50,000 population could have three children as a matter of course. These regulations were supposed to be in force from May, 1989. Because of political considerations, however, they were not put into effect until 1991 (Reuters, June 27, 1988; Sun, 1990; Hsieh Jiann, 1994:6; Zhang Tianlu, 1991:21). In the early 1990s about 80 percent of Xinjiang rural minority women were allowed three children and about 20 percent were allowed four. Some two-fifths of Xinjiang minority children were born outside the birth-control plan (Yasheng, 1990; 
Xinhua, August 5, 1992; Kynge, 19901.

Since 1992, "Family Planning Regulations for the Xinjiang Uygur Autonomous Region" have specified that urban Han can have only one child, while minorities can have two, with several exceptions allowing an additional child. Rural Han can have two children and rural minorities can have three (or more if all are girls). Within the region, local policies further increase the number of children allowed to minorities. In Kashgar Prefecture, four children are allowed minorities in border and mountainous areas and, exceptionally, five. On the other hand, rural Han are denied a second child if they live in specified counties and their child is a boy (Anderson and Silver, 1995:214 fn. 10; Zhang Tianlu, 1995; Xinjiang minwei, 1995, Yang Zheng, 1995).

In China as a whole, Han urban couples are generally restricted to one child. Exceptionally, a second child is permitted, so that urban fertility is about 1.5. Han farmers are in theory limited to one child, but exceptions swallow the rule or it is ignored. In practice, two children are permitted and many couples have three or more, but fail to register them (Xinhua, December 16, 1992; February 1, 1992; Deanne, 1992; Preston, 1992, AFP, January 23, 1995; Faison, 1997). For minorities, there is supposed to be a national default policy of two urban or three rural children (Gladney, 1991:164), but the policy is not applied in key parts of the country (Singer, 1997).

In 1981, nearly one-third of Xinjiang minority women aged between 15-19 had 
given birth to a child, while 2.5 percent of Xinjiang Han women of that age had done so (Yuan Qing-li, 1990:55). Although the overall Xinjiang birthrate fell sharply in the $1980 \mathrm{~s}$, from an average of four children in 1981 to 2.71 in 1990 , (Xinhua, February 1, 1992), in 1989 only 40 percent of Uygurs had just 1-2 children, in contrast to 82 percent of Han in the PRC. Some 15.5 percent of Uygurs had three children, 12.5 percent had four children and more than 30 percent had five or more. Total fertility for rural Uygurs was 4.77 ; for rural Kazhaks, 4.38 and for Xinjiang Han, 1.4 (Anderson \& Silver, 1995:215, 217; Gua \& Zou, 1993:43).

These differences partly stem from the higher share of minority peasants and the educational and occupational structure of minority communities (Poston \& Shu, 1987). Attempts to enforce birth limits in rural areas are however often resisted on religious grounds. Family planning work in the region has been characterized as "the most difficult work on earth" (Du, 1993), although resistance may be even greater in some Han provinces such as Henan and Shandong (Yang Zheng, 1995).

Penalties are locally set. In the early 1990s, an urban Xinjiang couple could be docked half a year's wages and fined 2,000 yuan (Holley, 1990). In Turpan Prefecture, the first violation, in theory, brings a warning and a 1,000 yuan fine, the next costs 7,000 yuan. In Kashgar, fines for each violation range from 1,000 to 10,000 yuan (Turpan and Kashgar officials, 1995). The authorities recognize, 
however, that a marketized economy makes it hard to implement birth plans by fiat (Xinjiang minwei, 1995), so that in practice, Xinjiang's rural Muslims may be one of those "well-organized minorities" who Dreyer (1993:254) says are "subject to little more than lectures on the wisdom of carefully planning the size of their families."

\section{B. Educational Preferences}

There were over 16 million minority students in China in 1995, up from 9.7 million in 1980 (Xinhua, November 17, 1995; February 16, 1981). The state claims a key role for preferential policies in this increase, via such allocative sources as the "Ethnic Minorities Education Aid Special Fund" (shaoshu minzu jiaoyu buzhu zhuankuan), Project Hope (xiwang gongcheng) and the Border Areas Construction Aid Fund (bianjing diqu jianshe buzhu fei). The education gap between most minorities and the Han remains substantial, however (Yang Chunpu, 1994). It will grow wider with marketized education, unless strong countervailing measures are taken. In 1994, the State Education Commission announced a five-fold increase in the central minority education budget to one billion yuan per year (Lamontagne, 1992:187; Lu Yumin, 1995; Xinhua, December 10, 1994). It remains to be seen whether this attention will counteract the effects of household labor needs, school fees, and other factors in producing increased illiteracy among minorities (Postiglione, et al., 1995; Zhang Tianlu, 1995). 
Apart from special funds for minority education, preferential policies are manifest in Xinjiang in some 400 boarding schools in minority pastoral areas (Xinhua, October 3, 1994). These give boarders "two exemptions" (liang mian), from payment for tuition and books, or "four guarantees" (si bao) of free food, clothing, lodging, and study materials. Staff-to-student ratios can be heightened at such schools and extra personnel hired in accordance with the area's ethnic characteristics (minzu tedian) (Chen, 1990:363; Lu Yumin, 1994; Xinhua, November 9, 1989a).

The percentage of minority university students increased from 1978 to 1992 , after declining in the late 1970s-early 1980s due to the reimposition of an entrance examination (Xinhua, December 4, 1979). The proportion of minority students fell again in the mid-1990s and is below the minority share of the population (see Appendix A). The likely cause is the marketization of higher education, which favors the more prosperous Han.

Most minority students attend home region universities, the Central Nationalities University or one of the 12 "nationalities institutes" (minz,u xueyuan) that are home to 16 percent of PRC minority college students. Minority universities do not have the same prestige as national universities and attendance at a minzu xueyuan may obligate a student to return to her home region (Cherrington, 1990; Daniels, 1984; Olivier, 1991:249).

Xinjiang has 21 colleges and universities. In the late 1980s-early 1990s, 
minority enrollment ranged from 56-60 percent. In 1994, the figure was put at 52 percent, but in 1997 Xinjiang's governor claimed it was 60 percent. A higher proportion of minority students are grant-aided than Han students (Xinjiang tongji nianjian, 1994:454; Xinhua, July 10, 1994; May 28, 1994; January 20, 1992; November 11, 1991; August 15, 1991, April 24, 1990; October 28, 1980; AFP, May 12, 1997).

Minority enrollment varies from school to school. Hotan and Kashgar teachers colleges are 90 percent minority (Kormondy, 1995: 166, 168; Xinjiang jiaowei, 1995). Xinjiang University, the only comprehensive school (zonghe daxue), was 50 percent minority in 1995, down from 60 percent in 1986 . Xinjiang Medical College and Xinjiang Industrial College are mostly Han. In 1994, 701 of 952 students from Turpan who began college were ethnic minorities, with the vast majority entering local institutions. Some 48 percent were Uygurs, although the latter are 78 percent of Turpan's population, while 43 percent were Hanyuspeakers (Han and Hui), although these groups only constitute 22 percent of the population. The Han share of univers ty students is increasing due to a regionwide growth in self-supporting (zifei; zikaoban) students. Han are mainly urban and can better afford the 2,000 yuan anuual fee, while 77 percent of Xinjiang's minority tertiary students are from peasant families. While many are government-aided and need only pay 900 yuan per year, this fee is beyond the reach of some students (Xinhua, February 7, 1986; Turpan official, 1995; 
Xinjiang jiaowei, 1995; Xinjiang minwei, 1995).

A small proportion of minority students attend key national universities, where their share is a bit below the national average, e.g. six percent at Beijing University and five percent at Lanzhou University (Kormondy, 1995:162). Xinjiang minorities schooled outside the region are usually part of Xinjiang cohorts ( $\mathrm{ban}$ ), set up by agreements between Xinjiang and universities. In 1987, cohorts existed at 14 universities and enrolled 450 students. By 1994, 5,000 students had been trained in the program and 54 neidi institutions pledged to train 5,450 Xinjiang students in 1995-2000, an effort coordinated by Conferences on Cooperative Projects of Interior Universities Supporting Xinjiang Education (neidi gaoxiao zhiyuan Xinjiang jiaoyude xiezuo xiaomu) (Amat, 1991:1; Lu Yumin, 1994; Ba Jiankun, 1989:306; Xinhua, July 28, 1995; Xinjiang minwei, 1995).

Ethnic cohort students sign contracts agreeing to return home upon graduating, where they are tracked into a limited number of work-units. In most instances, an ethnic cohort means an extra year of study (Postiglione, 1992:39; Zhang Yenming, 1991:183-186). There are also preparatory courses (yuke ban) for minorities, which may be either one-year programs for students who failed to enter a university through the national enrollment system or a long-term program for promising secondary-level minority students. By the end of $1980 \mathrm{~s}, 40,000$ minority students had passed through yuke ban and in 1996, 11,000 were 
enrolled in them at 138 institutions in 20 provinces (Zhongguo jiaoyu nianjian, 1984:411; Xinhua, November 23, 1989; June 17, 1996).

Universities are adjured to "give ethnic minorities priority over others with equal qualifications." In fact, minorities are eligible for admission with lower entrance examination scores as a matter of course (Xinhua, January 12, 1992; Zhang Yenming, 1991). Generalizations about the number of extra points given to minorities have been made (Rossett. 1991:1520 [10 points]; Guldin, 1991 [10 points]; Kormondy, 1995:167 [20 points]; Kwong and Hong, 1990:233 [30 points]; Lu Yumin, 1994 [10-80]; Zhang Tianlu, 1995 [20-100]). The degree of advantage, however, varies annually and in a much wider range than has been supposed.

Many factors determine the number of extra points given to a minority applicant, including home region, ethnicity and course and language of study (Sautman, 1997a). Minorities who take the exam in Chinese (min kao han) and those who take it in a minority language ( $\mathrm{min} k a 0 \mathrm{~min}$ ) are accorded different preferences. For example, the few Kashgar students who are min kao han are spotted 80-140 points (out of 750), except for the Hanyu-speaking Hui minority, which is given 10-20 points. The cut-off point (fenshuxian) for admission of min kao min into the three local institutions where most end up is largely determined by how many students these schools can admit, which is in turn a function of the needs of local work-units (Kashgar official, 1995). 
The points needed to apply to universities outside the minority areas depend upon the annual configuration of the minimum by province, track (science or liberal arts), sex, university status ("key-point" or not) and other factors. The points needed by a student from Jiangsu, for example, always exceed those needed by a Xinjiang student. If the central authorities decide to boost minority enrollment generally, as they did in 1991, or increase the Xinjiang students at hinterland universities, as they did in 1989 , they can lower the minimum needed by Xinjiang students. Xinjiang Han students are also favored by this system, although the universities may offer a further preference to Xinjiang minorities (Amat, 1991:5; Xinhua, November 9, 1989a). Still more bonus points are accorded to Xinjiang "frontier, mountainous and pastoral regions" students (Zhang Yenming, 1991:211).

Actual differences in the average scores of minority and Han admittees are higher than the differences between minimum scores. In 1986, admitted Xinjiang Han averaged 435 points in science and 440 points in liberal arts; minorities averaged 300 points in science and 245 in liberal arts. In 1987, Xinjiang Han admitted to key universities averaged 470 points in science and 445 in liberal arts; minorities averaged 313 and 269 points (Ba, 1989:304). The average difference in actual points attained has diminished in the 1990s however (Wang Jiamin, 1995).

In some cases minority students need not take the regular national 
examination; schools that teach in minority languages can have their own exams. A minority student who applies where Hanyu is used may take the entrance examination in her native language or take a simpler "B Text" entrance exam in Hanyu (Postiglione, 1992:38; Olivier, 1993:242: Loftstedt, 1987:337).

The central government and the autonomies have tried to boost the number of minority tertiary faculty. Their percentage still lags behind that of minority students and the vast majority teach at minority colleges or minzu xueyuan (see Kormondy, 1995:162). Given the constricted pool of potential minority faculty caused by training most minority students to be primary and secondary teachers or cadres, however, the effort to recruit more minority faculty must be credited with some success (see Appendix B).

Preferential policies are pervasive in the educational system. Absent the special funds and liberal admissions requirements, there is no doubt that a much smaller number of minority students would be able to attend school. In the early 1980s, it was decided that in Inner Mongolia 20-25 percent of university students should be from minority backgrounds and estimated that without providing 10-15 point examination advantages, not more than two percent of those admitted would be minorities. While the advantage needed by minority students has diminished (Wang Jianmin, 1995; Rong Shen, 1995), preferences are still needed to keep minority enrollments at the designated, although still generally less than proportionate, levels. In fact, preferential policies in 
education may have to be augmented to reverse the tendency for the proportion of minorities to fall as the social stratification of the educational system proceeds.

Finally, the effects of affirmative action in education should be noted. In Xinjiang in the 1980 s, ethnic inequality declined for the transitions to upper middle school and college and ethnic occupational inequality eased somewhat. By 1990 , a Xinjiang minority person with a high school or university education had a better chance of gaining an elite position than an equally-educated Xinjiang Han. This indicates that for minorities who manage to gain access to higher education, affirmative action plays its intended role of enlarging and diversifying the minority middle class (Hannum and Yu Xie, 1995).

\section{C: The Hiring and Promotion of Minorities}

Mao once adumbrated that the solution to the "nationalities problem" lay in training large numbers of minority cadres, a prescription inserted into the LRA (Amat, 1991; Ngapoi, 1984). Despite the state's retreat from some areas of former dominance, cadres are still a glue that binds Chinese society. In 19921993, 2.28 million of the 32-34 million cadres were minorities (Pan Qi, 1993; Crothall, March 23, 1993). Minorities are underrepresented among Han area cadres, but often overrepresented in autonomous areas (Becquelin, 1997:20; Xinhua, April 24, 1997). In 1995, 10.5 percent of ministerial and provinciallevel cadres and 7.9 percent of bureau and prefecture-level cadres were 
minorities (Xinhua, December 27, 1995). LRA Article 17 mandates that top officials and "as many members as possible" of eponymous ethnic groups serve as heads and work in autonomous areas governments (Renmin Ribao, June 4, 1984).

The concept of giving preference to minorities to fill state leadership positions in autonomies was extended in 1994 below the county level. "Regulations on Ethnic Township Administration" (minzu xiang xingzheng gongzu tiaoli) (Zhongguo minzu tonji nianjian, 1994:25-27) Article 4 specifies that government personnel in ethnic townships should as far as possible, be drawn from the minority population. While written in precatory language, the provision is likely taken as a prescriptive.

The disproportionately high percentage of top-ranking minority state officials says nothing, of course, about their efficacy. It is a truism in China that party heads are more powerful than state officials, yet the CCP has no internal preferential policies. Minority area party secretaries need not be "ethnic" and often are not, while minorities are underrepresented in Party ranks. There were 2.8 million minority CCP members in 1990, 5.7 percent of the party (Minzue Tuanjie, 1991; Mackerras, 1994:157). There are allusions to "a relatively big growth" in minority CCP membership (Xinhua, June 5, 1991), but in fact growth has been slow. In 1995, with CCP membership at 57 million, minorities were still only 5.8 percent of the Party or about 3.19 million, although 7.3 percent of 
new recruits that year were minorities (Xinhua, June 29, 1995; June 13, 1996). Minorities are wholly lacking at the top: all 21 Politburo members are Han. There have been only three minority people among more than one hundred persons who have served on the body since its inception. At one time or another, four autonomous regions (all except Tibet) have had a regional Party Secretary from a local minority, but none have continuously had one (Huang Gongxue, 1993:315-316).

With no internal preferences and a scarcity of minorities in the Party ranks, there is no guarantee that minorities will not mainly be relegated to the state nomenklatura, where preferences must be applied. Other factors make this outcome still more likely. The mantra that there are "large numbers of politically reliable and professionally competent minority cadres in China" is often repeated (Xinhua, December 15, 1994), but the invidious stereotype is propagated of minority cadres retaining the "backwardness" of their cultures.

One scholar has put it that

The economic and cultural backwardness of the minority peoples that results from historical reasons and their location in remote areas, as well as the definite influence on the psychological make-up of minority nationality cadres of the enduring nature, public nature and complexity of their religious faith means that minority nationality cadres mature slowly (Yao Zhongwu, 1992:1).

This perception calls into question the professional competence of minority cadres and "security" considerations often call into question their political 
reliability (Davis, 1997:12). The results are seen in Xinjiang: minorities were only 40 percent of the party membership in 1990; an even smaller proportion of the Party leaders are minorities (Dreyer, 1994:53; Kostrzewa, 1996:240).

In Turpan, the three Party secretaries in office from the end of the Cultural Revolution until the early 1990s were Uygurs. The current Party secretary is Han, the staff of the Party organization departments (dang zuzhi bu) and all county secretaries since 1991 have been Han, a reversion attributed to the Party's reaction to separatist incidents (Turpan cadre, 1995; Turpan official 1995). In Kashgar, more than half of the Party Committee members are Han or Hui, although these groups are only 19 percent of the population (Kashgar official, 1995).

The dualism of ethnicity of party and state leaderships is freely admitted by Xinjiang officials. Although it is claimed that it is not a deliberate policy, but "has emerged from practice" (zai shishizhong chuxiande) (Xinjiang minwei, 1995), the duality is deemed objectionable by some minority cadres. In Turpan, minority cadres have protested against Han leadership of the local Party and, as the practice remains, have come to regard the central government as "all talk, no action" on the issue of minority leadership (Turpan official; 1995; Turpan cadre, 1995).

Although the preference for minorities in the top state ranks coexists uneasily with an absence of preferences for Party positions, minorities are better 
represented in the cadre ranks than they were in the not-too-distant past (see Appendix C). In many places, the upsurge of hiring and promoting minority cadres came in the 1980s, with marginal growth later. Top leaders realize that there is still a deficit in minority cadres and Hu Jintao, the Politburo Standing Committee member in charge of ethnic minority work, has declared that it "imperative to step up the training" of minority cadres (Xinhua, September 23, $1994)$.

In Xinjiang in 1995, there were 270,000 minority cadres, 46 percent of the total, a figure that has not varied much since the early 1980s (see Appendix D). In the mid-1990s, the chair of the regional government (but not the Party secretary), seven of eight vice-chairs of the region's people's congress, the heads of all prefectures and cities and their highest judicial officers were all minorities, as were 83 percent of county heads. Some 67.6 percent of regional bureau directors were minorities, but most assistant heads were Han. Minorities were also less prevalent among department or division level regional government officials -- 43.6 percent and 21.5 percent respectively (Xinhua, September 24, 1995; December 12, 1994; April 24, 1993; February 5, 1993; Xinjiang minwei 1995; Huang, 1993:316).

Minorities in top-level slots thus coexist with an overall underrepresentation of minority cadres in Xinjiang. The pattern is also found locally. In Kashgar, 90 percent of the population and 75 percent of cadres are minorities. In Turpan, 
minorities are 78 percent of the population, but Han and minorities occupy halfshares of county-level cadre positions. There are, moreover, cleavages in the sectors of government in which minorities and Han serve. In Turpan, the two county chiefs and the heads of the two people's congresses and consultative committees are minorities, but among leading state cadres a division of labor is in effect, as a matter of "natural form" (ziran xingcheng) according to one official. The banks, financial offices and enterprise organization departments (danwei zuzhi bu), the economic planning commissions (jihua weiyuanhui) and other key organs are largely composed by Han. The united front work, ethnic and religious affairs departments are the province of minorities. In Kashgar, Han lead in financial matters and science and technology; minorities lead ethnic and educational work (Kashgar official, 1995; Turpan official, 1995; Turpan cadre, 1995).

Some minority cadres attribute the underrepresentation of their ethnic groups in Xinjiang cadre ranks to lower education levels. They are aware that much power over minority area affairs remains at the center (see Lam, 1993; He Pin, 1991; Barnett, 1993:659; Gladney, 1991:160). They also know that a mere increase in the numbers of leading minority cadres does not mean that decisionmaking authority will accrete to local organs. These cadres do, however, credit preferential policies with ensuring that minority representation is higher than it would be given the educational disparities (Turpan cadre, 1995). 
No matter how effective preferential policies may be when minority people seek cadre positions (zhao gan), they are less of an advantage in seeking a job as an ordinary worker or clerk (zhao gong). The 1993 "Regulations on Work with the Urban National Minorities" Article 8 states that municipalities should encourage enterprises to recruit minority workers (Zhongguo minzu tongji nianjian, 1994:27). Minority status may be specified for a position or a minority quota fixed because a business is specific to minority needs. In Kashgar, for example, at least half of all Muslim food industry workers must be minorities. Many working class jobs require an examination on which minority applicants receive bonus points (Kashgar official, 1995; Wang Jianmin, 1995). On the employment examination in Urumqi's Oil and Chemical Factory, for example, Han applicants need to score 250 points; minorities can pass with 120. A 25 percent minimum minority quotil exists for large Xinjiang state enterprises. Prefectures, counties and other localities also have job quotas that reflect the composition of the population. While some enterprise do not fill their quotas, others exceed them (Li Ze. 1995).

Some undertakings are exempt from quotas. In the Taklamakan Desert oil exploration program in 1995 there were only 253 minority people among 4,000 technical workers (Johnson, May 31, 1995). Among 20,000 oil workers in the Tarim Basin, few jobs have been allocated to minorities (Chen, October 21, 1994; AFP, May 13, 1997). The Regional Party Secretary, Wang Lequan, has 
stated that "The workforces in Xinjiang's oilfields all come from other oilfields in China so we don't take local people" (Reuters, April 25, 1993). It is also argued that only petroleum technical school graduates can be employed in the initial development of an oil field and that few such workers are available in Xinjiang. In the older Karamai oil fields, it is claimed, there is a high ratio of minority workers (Li Ze, 1995).

Some employers seek to undermine quotas. In Turpan, the ratio of minorities in factories is decreasing because Han directors prefer Han workers and township governments have no power over township contracted enterprises in terms of the ethnicity of hirees. While some enterprises contracted to minorities employ minorities, those contracted to Han people usually employ only Han migrant laborers. A local official put it that the LRA is of no use (bu guan yong) now because the Law on Enterprises (qiye fa) has no preferential policies provision.

In Kashgar, where minorities are not hired to the extent deemed warranted by their overwhelming numbers, ethnic affairs cadres try to get more minority workers hired. Officials acknowledge, however, that with marketization, quotas are now problematic. In the textile industry, for example, Han and minority workers each have a half-share of employment and officials opine that they have to devise new quota policies for the private sector (Xinjiang minwei, 1995; Turpan, Kashgar officials, 1995). 


\section{D: "Representative" Bodies}

The PRC's statutory legislative organs are commonly ridiculed as "rubber stamps" of decisions already made by the CCP (Tyler, 1995). People's congresses do not enjoy the plenary lawmaking powers of liberal democratic parliaments and PRC legislators have only modified, never aborted government proposals. The rubber stamp image nevertheless is increasingly a caricature (Dowdle, 1996; O’Brien and Li, 1993; 1994; Johnson, March 4, 1995). Modifications, temporary obstruction and negative votes cast against proposed laws by NPC members do impact the shape of the less controversial pieces of legislation (see Tan Tarn How, March 29, 1995; Reuters, March 14, 1997). Even the tame Chinese People's Political Consultative Conference (CPPCC), which includes the eight satellite parties, former minority elites and "leading personages," now at least provides feedback to the top CCP leaders (Tan Tarn How, March 4, 1995). Regional CPPCCs may go beyond this role. Even the Tibetan exile leaders have remarked that "debate within the [Lhasa] Consultative Conference is much more open, rancourous and divisive than previously believed" (International Committee for Tibet, 1994).

While minorities have always been a high percentage of National People's Congress (NPC) and national CPPCC: members, the figures have fluctuated with the viscissitudes of minority policy. The Sixth NPC in 1983 enacted a law that requires that at least 12 percent of NPC members be minorities (Ao Junde, 
1991:6-7). In recent years, the NPC and national CPPCC figures have stabilized at a level substantially higher than the minority share of the population (see Appendices E and F), a pattern that will persist for the Ninth NPC (Xinhua, May $6,1997)$.

Other bodies also include minority quotas. Over one-tenth of CCP Central Committee members are minorities (see Appendix G). Minority delegates to the CCP Fifteenth Party Congress in 1997 were 10.7 percent of the total (Lam, 1997). At the Seventh All-China Federation of Women congress in 1993, 14.3 percent of delegates were minorities (Xinhua, August 25, 1993). In 1995, of 2,873 model workers commended by the All-China Federation of Trade Unions, 8.3 percent were minorities (Xinhua, April 26, 1995).

The least that inclusion of many minority people in the NPC should ensure is that attention be paid to ethnic questions. From 1979 to 1995, the NPC passed some 200 laws, about 40 of which had provisions dealing with "ethnic issues" (Xinhua, March 3, 1996). These provisions were largely the work of the NPC Nationalties Committee. The CPPCC Subcommittee of Nationalities and Religions mainly carries out investigations, but its work sometimes leads to legislation or new regulations (Xinhua, March 5, 1997; February 27, 1996; March 29, 1993).

Heightened minority representation at lower and presumably more meaningful levels of the political system is also required. The PRC Constitution mandates 
that minorities be represented in urban resident committees (jumin weiyuanhui) and villager committees (chumin weiyuanhui). The Electoral Law has a "setaside" for minorities in local people's congresses outside the autonomies (Xinhua, February 28, 1995). Xinjiang's regional people's congress in 1995 had 540 members, 357 (66.1 percent) of whom are minorities and 235 (43.3 percent) of whom are Uygurs. Among $58 \mathrm{NPC}$ deputies from Xinjiang, 36 (62 percent) are minorities and 22 (37.9 percent) are Uygurs, not coincidentally the same percentages of minorities and Uygurs in the Xinjiang population (Xinjiang minwei, 1995). Of 14 chairmen of the regional CPPCC, nine were minorities in 1993 (Xinhua, February 5, 1993).

The requirement of a large minority presence in legislative bodies provides many minority figures with entree into the precincts of leadership. It allows delegates to advance their own individual interests and those of minority members within their networks. While some observers would leave it at that, the large minority presence is not entirely a sop. Without it, the scope of China's preferential policies would likely be narrower. The extent to which minority PRC legislators actually represent minority interests is not yet clear, but when the concept is posed to Xinjiang officials, it strikes them as novel and sensitive, but not out of the question. Minority politicians, it seems, can press for measures to benefit minorities without committing the delict of "local nationlism" (diqu minzu zhuyi). 
These deputies may increasingly abandon their quiesence and seek additional preferential policies. A 1994 poll of regional ethnic affairs officials showed that all believed that the gap between minority and coastal areas was an urgent problem. Two-thirds stated that the ethnic question would become increasingly acute (Hu Angang, 1994). The gap is indeed growing. From 1978-1990, overall PRC GNP grew by 2.37 times; minority areas GNP grew by 1.69 times (Ma and $\mathrm{Li}, 1992$ ). The ratio of investment in capital construction in state-run enterprises in minority areas to total inv estment in PRC capital construction fell during the past two decades. The ratio of total value of agricultural and industrial output in minority areas to that of the whole country, which was 7.85 percent in 1949 declined to 7.20 percent by 1990 (Chen Jianyue, 1996:20-21; Zhang Huijun, 1996:31).

Xinjiang leaders are discontented with the growing gap between minority and Han areas. This unhappiness is acknowledged at high levels of the CCP (Song Hanliang, 1994; A. Cheung, 1995; Xinhua, September 8, 1994) and may be one reason why the center has pledged to double investment in infrastructure during the Ninth Five-Year Plan (1996-2000) over its investment during the Eighth (1991-1995) (Xinhua, March 18, 1997). Han people have also been able to take greater advantages of business opportunities within the minority areas. If minority deputies stand silent in the face of the erosion of the position of minorities their credibility will diminish. It would not be surprising then if they 
were to become more vocal over economic and social issues.

\section{A Multiplicity of Resentments; a Paucity of Tensions}

Preferential policies, it is said, are "likely to create jealous resentments among the Han" that will diminish positive attitudes toward minorities by the state (Rosett, 1991: 1525-1526). There are, indeed, accounts of Han resentment toward preferential policies that extend from the $1950 \mathrm{~s}$ to the present (Borchigud, 1994:287; Gladney, 1995:246; Singer, 1997), yet Western journalists who broach the subject with ordinary Han in minority areas report that resentment is not noticeable (Kristof, March 31, 1991; Lovell, June 24, 1981). There is little of the concern about quotas that animates discussions of affirmative action in the US, for example (see Eastland, 1996), in part because in China there is a quota for everything, from the number of university students to be sent abroad to the number of executions (Wong, 1994).

Beneficiaries of preferential policies also live mainly in the autonomies, which were ostensibly established to create a sense of territorial proprietarship for their autochthonous peoples. While the Han are more than guests in these areas, many recognize that some privileges inevitably attach to autonomous status. The same phenomenon was noted among non-eponymous peoples in the Central Asian republics of the ex-Soviet Union. Answering queries about the equity of preferential policies accorded to their Muslim neighbors, these mainly Slavic respondents would often state that it is, after all, their republic (Karklins, 
1986:66).

There have been occasional calls to scrap preferential university admissions on grounds of quality control and equity (Ye Zhaoyang, 1994). These preferences, however, are said to be "not a sensitive social issue in China because a college education does not make much difference in social rewards, particularly income" (Pyong, 1990:16). This may be changing. While there was no strong correlation between education and income during the egalitarian Mao era and only a weak one in the get-rich-quick Deng era, professionalization and the need for a higher skill-level to do business should produce a closer tie. Preferential admissions may then become a subject for debate.

Such resentment as exists mainly concerns family-planning (Brugger \& Reglar, 1994:337; Gladney, 1991:164; Rosett. 1991:1552; Wren, 1983). The Han in Xinjiang are said to be the most vocal complainants in the country about family planning preferences for minorities (Zhang Tianlu, 1995). Resentment seems most concentrated in Urumqi; a candid cadre in Turpan has stated that there is little jealousy of minority family planning advantages shown by local Han (Turpan official, 1995). To Turpan's small Han population, perhaps, "it is their prefecture." In Kashgar, minority people complain that family planning is too lax among the Han floating population. There are reportedly no complaints from settled Han about family planning preferences given to local minorities (Kashgar official, 1995). 
There are also indications of resentment by Han of minority people using local political power to practice ethnic nepotism with regard to employment (Wu, 1990:7), a frequent complaint of non eponymous people living in Central Asia before the demise of the Soviet Union (Gittelman, 1990). There are, however, no reports of claims that preferences generally result in hiring unqualified employees in China, in contrast to the United States, where such complaints are common despite studies that show that affirmative action hirees and minority contractors are not less qualified than others (Holzer and Neumark, 1996; ENR, 1997).

Resentment of preferential policies is not a singularly Han phenomenon. Some minority people also have reservations. Among minority students admitted under a quota system, some who had a hard time with their studies have felt inferior to their Han classmates. (Zhang Yenming, 1991:238). Some minority students, noting the mobility of their Han classmates, also resent the requirement that they return to their home regions after study in the hinterland (Hong Kong Standard, 1989). These students see "special admissions" as a double-edged sword which improves their lot, but with costs. There is no indication, however, that any student is unwilling to pay this price for access to education.

Minority family planning preferences also have a downside. The state provides benefits to couples who accept the "one-child certificate" (dusheng zinu zheng). In Xinjiang in 1995, a 10 yuan monthly subsidy is paid to each only- 
child until his or her 18 th birthday and the mother can extend her salaried maternity leave by 30 days. Elsewhere, those who take advantage of preferential family planning policies to have a second child may lose the benefits of the certificate, but in Xinjiang, minorities with only two children receive a "Family Planning Honor Certificate" (jihua shengyu guangrong zheng) that is treated as equal to the one-child certificate (Yuan Xin, 1994:14). The benefits offered are often not consequential, but better urban housing and retirement terms and better rural land allocation may come into play, depending upon the locality (Yang Zheng, 1995; Banister \& Harbaugh, 1994:901-910). Even these added benefits, however, are not sufficient to induce most rural Han to accept the certificate (Cooney \& Li, 1995:26). Rural minorities, who are more likely than Han to hold religious convictions that favor large families, will also often forgo the benefits of the certificate.

While some minorities note these problems, the more common reaction is to regard preferential policies as still too weak to overcome the gap in education and living standards between most minorities and Han (Wu and Long, 1985:8687). All preferential policies, whether they be preparatory education for students, health care services for an additional nomad child or central government participation in the electrification of a minority county, involve direct or hidden costs. The richer the area, the more likely programs are to be implemented, because higher levels of government will often fund programs 
only if lower levels do so as well (Zeng Zhaohua, 1992). Most minority area governments are strapped for funds, however. Costly policies can easily go by the boards precisely where they are needed most.

While no one disputes that preferential policies are generally valued by minorities, some minority intellectuals see them as half-measures because they do not provide a solution to the erosion of indigenous cultures. Indeed, they can be seen as contributing to cultural erosion by bringing more minority students into the higher levels of schooling where Hanyu is vital. Economic development in minority areas also attracts Han migration. The Han in Xinjiang, for example, were only 6.2 percent of the population in 1953 , but 38 percent twenty years later (Schwarz, 1963:69; Heberer, 1989:93). Migration has engendered economic competition that has not been fully addressed by preferential policies. In Xinjiang, lncal construction contractors complain that they cannot effectively compete with companies that come from the hinterland. Local people are urged to learn from Han business practices and told that their culture is so deeply embedded that it is not threatened by demographic change, but many doubt that the former is practical or the latter true (Xinjiang minwei. 1995; Kashgar official, 1995). Resentment over the Han influx thus has led to clashes between minority people and the state in Xinjiang (Peters, 1991:152; Kostrzewa, 1996:243-246). Even ordinary local Han are reportedly opposed to a further Han influx and Xinjiang political leaders, both Han and Uygur, have 
objected to unlimited migration (Xinjiang Ribao, April 9, 1993; Reuters, March 19, 1997).

Preferential policies are also perceived as not ensuring an equitable depletion of local natural resources (Zhang Huijun, 1996). The central government argues that most extractable Xinjiang resources are used locally and that it gives more in subsidies to Xinjiang than its profits from all regional sources (Xinhua, March 26, 1997). Xinjiang officials, however, complain that central and foreign companies derive most of their profit from local oil, with not much going to indigenous peoples (Lam, 1996; Xinhua, September 23, 1995; Ferdinand, 1994:279; Wei Xiang 1990). They note that 30 percent of tax income from Xinjiang oil and 50 percent of tax income from products of the Urumqi Chemical \& Oil Products Co. go to local government (Xinjiang minwei, 1995; Turpan official, 1995), but are not satisfied with those shares.

There is thus a multiciplicity of resentments, petty and potentially grand, over preferential policies. Among minorities, affirmative action may be considered to be too weak. Among Han what is striking is that despite the wide variety of issues raised in public protests by students, intellectuals, workers and others -on issues ranging from poor school cafeteria food to corrupt and arbitrary conduct by officials -- there is no recorded instance of a mass protest about preferential policies for ethnic minorities. Han cadres working in minority areas do grumble about the glass ceiling caused by ethnic quotas, but they have the 
option of returning to the hinterland. Many do, contributing to an internal "brain drain" from inland China to the coasts created by economic liberalization. In 1988-1994, 6,000 scientists left Xinjiang alone. For every professional who settled in Xinjiang and Ningxia in 1991-1994, six left for east China (Zhang Tianlu, 1995; Lam, March 30, 1995).

As it now stands, resentments over preferential policies do not translate into "tensions," in the sense of manifest discontent over preferences given to minorities. One reason is that many Han and some minority people accept the social evolutionary schema that is the centerpiece of the theory of Han-minority relations in the PRC. Another reason is that university admissions are expanding rapidly; opportunities abound for Han with skills or connections. Seats in legislative bodies have yet to become so sought-after that ethnic-based set-asides can generate much heat.

In short, there are few incentives for Han to raise the issue of preferential policies. Those who are most likely to do so -- the Han who live in minority areas -- are often third-party beneficiaries of preferential policies. For example, students must pass a preliminary exam in order take the national entrance examination. Whenever the number of Xinjiang minority students who pass the preliminary exam is less than the number of places set aside in universities for minorities, the quota can be used by Han students. The result is that some Xinjiang Han gain places at universities outside the region that were doubtless 
originally set aside for minorities (Xinjiang Han student, 1995). But for the area-based preferential policy of rapidly expanding the number of university places in minority areas, moreover, many university places taken by Xinjiang Han students would not exist.

Only the family-planning preference might give rise to tension. Thus far, however, it has mainly induced jealousy. Family-planning has eased in the countryside, where demand for more children is highest. In the cities, higher education levels and the increased cost of child-raising have led to acquiesence in the one-child policy. In Urumqi, when Han complain about the preferences given to minorities, it is not to express a desire for a second child, but to affirm the one child policy and deplore that minorities do not conform to it (Zhang Tianlu, 1995).

Rural Xinjiang Han can be said to benefit from preferential policies for minorities in family planning, as they can have two or three children as a matter of course. Family planning liberality for Han farmers is solely a function of the fact that their Uygur and other minority neighbors themselves enjoy one of the most liberal policies in China (Xinjiang jıaowei, 1995). It is not likely then, that tensions will emerge from the Han side over this uniquely Chinese feature of preferential policies.

III. Conclusion: The Chinese case and the international debate

The thrust of the case against affirmative action made by some comparativists, 
most notably Sowell and Weiner, is that it is a brake on economic growth, a source of destructive ethnic tension and a disincentive to minority accomplishment. China's growth rate, however, is among the world's highest, with slower, but still rapid growth in most autonomies. Gross domestic output value for PRC minority areas in 1996 was up 10.5 percent and for Xinjiang nine percent (Xinhua, March 8, 1997; Xinjiang Ribao, March 14, 1997). There are resentments, but little tension, over preferential policies, let alone discord that might threaten social stability. Great tensions do exist in Han-minority relations, but these derive from a host of specific minority grievances (see Kostrzewa. 1996:235-268) and from Han chauvinism (da hanzu zhuyi) and the resulting rejection by some minority people of the state's supranationalist concept of a "Chinese nation" (zhonghua minzu) (see Sautman, 1997b; Bjorn, 1994).

The dependency question raised by critics of preferences needs to be disaggregated in the Chinese case. Article 33 of the LRA provides for subsidizing autonomies. PRC leaders are aware that this creates dependency and urge these areas to display more self-reliance (cf. Chan, 1996). Part of the preferential policies structure is designed to allow the minority areas to do just that. LRA Article 35 permits the autonomies to specially lower their taxes. thereby improving the climate for investment and partially compensating for the greater state investment in China's coastal areas (Chen Jianyue, 1996). The industries of Xinjiang and other autonomies also bencfit from mandatory aid 
from more prosperous enterprises in east China (Xinhua, March 13, 1993), including technology transfer that should lead to less dependence. The same result should follow from programs in which Beijing and Xinjiang cadres are swapped for fixed periods (Lam, 1994). In Xinjiang, preferential programs aimed at minority individuals, moreover, are not ones based on idleness: local banks must provide low interest loans to minority borrowers who will use the money to start businesses, with the nominal interest paid by the prefecture (Turpan official, 1995).

The Xinjiang case indicates that China's preferential policies have not necessarily fulfilled the pessimistic scenario of some comparativists. China may be an aberrant case that scholars can ignore, as a statistician disregards an outlier. That, however, is difficult, given the comprehensiveness and size of the program of preferences in the PRC.

Preferential policies alone will not eliminate the conflicts in minority areas that have sometimes generated violent clashes. These policies are, after all, set within the context of the paternalistic and hierarchical approach to ethnic relations adopted by the Chinese government. When minorities avail themselves of preferential policies they often seem to fulfill the tenets of the government's social evolutionism. Nor will tensions necessarily evaporate through economic growth, as is assumed by the PRC leadership. A host of other problems would remain even if the economic gap were to narrow, particularly the question of the 
erosion of minority cultures, which remains unaddressed by preferential policies. These policies exist, however, precisely because the Han-minority gap is not narrowing and because ethnic relations are marred by many other factors. The readily observable positive correlation between the degree of ethnic strife and the breadth of preferential policies in the various minority areas indicates that preferences exist precisely because there is dissatisfaction in minority areas. The alienation of many minority peoples cannot be overcome by preferential policies, but these policies will probably continue in China for as long as substantial solutions to the country's ethnic problems remain elusive.

If preferential policies did not exist, tensions would likely be even higher than they are at present because avenues for maintaining aspects of minority lifestyles and for advancement into the middle class would be closed. Again paradoxically, preferential policies stand as the regime's hope to construct a loyal minority middle class and, at the same time, as a factor for the creation of opportunities by minority people themselves. 
Appendix A: Minority Students at PRC Universities

\begin{tabular}{||l|l|l||}
\hline Year & Number of Students & Percentage \\
\hline $1949-1950$ & 1,285 & 0.93 \\
\hline $1950-1951$ & 2,117 & 1.36 \\
\hline $1951-1952$ & 2,948 & 1.52 \\
\hline $1952-1953$ & 5,536 & 2.56 \\
\hline $1953-1954$ & 7,999 & 3.10 \\
\hline $1954-1955$ & 8,833 & 3.04 \\
\hline $1955-1956$ & 14,159 & 3.47 \\
\hline $1956-1957$ & 16,101 & 3.62 \\
\hline $1957-1958$ & 22,421 & 3.39 \\
\hline $1958-1959$ & 28,163 & 3.47 \\
\hline $1960-1961$ & 29,921 & 3.16 \\
\hline $1961-1962$ & 28,729 & 3.45 \\
\hline $1962-1963$ & 24,825 & 3.31 \\
\hline $1964-1965$ & 21,870 & 3.24 \\
\hline $1974-1975$ & 30,607 & 6.11 \\
\hline $1975-1976$ & 36,578 & 6.48 \\
\hline $1976-1977$ & 34,460 & 5.51 \\
\hline $1977-1978$ & 36,030 & 4.21 \\
\hline $1978-1979$ & 37,378 & 3.66 \\
\hline $1979-1980$ & 42,944 & 3.75 \\
\hline $1980-1981$ & 51,220 & 4.00 \\
\hline $1981-1982$ & $53,-139$ & 4.66 \\
\hline $1982-1983$ & 59,630 & 4.94 \\
\hline $1983-1984$ & 69,633 & 5.0 \\
\hline $1984-1985$ & $94,(195$ & 5.3 \\
\hline & & \\
\hline
\end{tabular}




\begin{tabular}{||l|l|l||}
\hline $1985-1986$ & 99,468 & 5.3 \\
\hline $1986-1987$ & 118,735 & 6.1 \\
\hline $1987-1988$ & 125,422 & 6.1 \\
\hline $1988-1989$ & 131,599 & 6.3 \\
\hline $1989-1990$ & 137,948 & 6.6 \\
\hline $1990-1991$ & 141,767 & 6.9 \\
\hline $1991-1992$ & 152,858 & 7.0 \\
\hline $1992-1993-1994$ & 163,224 & 6.4 \\
\hline $1994-1995$ & 178,000 & 6.4 \\
\hline $1995-1996$ & 160,000 & $5.7^{*}$ \\
\hline
\end{tabular}

Sources: Zhongguo minzi tongji nianjian, 1949-1994 (1994), 344-345: Guo Sheng, $\boldsymbol{t}$ t al., 1989, p. 298. Zhongguo shehui tongji ziliao, 1993:170, 182: State Education Commission, Minority Education Department, private communication, 1996; Zhang Yenming, 1991:160, 233; He Jiangcheng, 1990; Liu Yingjie, 1993:2048; Chen Hongtao, 1990:363, 383; Ministry of Education, 1984:107; Amat, 1991; 1992; Xinhuta, November 21, 1995; September 29, 1991, Zhongguo Xinwenshe, September 23, 1993; September 16, 1983; Kwan, 1995; Reuters. October 25, 1995. 
Appendix B: Minority Faculty at PRC Universities

\begin{tabular}{||l|l|l|}
\hline \hline Year & Number of Faculty & Percentage \\
\hline 1953 & 623 & 1.85 \\
\hline 1957 & 1,941 & 2.8 \\
\hline 1965 & 3,311 & 2.4 \\
\hline 1976 & 3,020 & 1.8 \\
\hline 1978 & 5,876 & 2.8 \\
\hline 1979 & 7,150 & 3.0 \\
\hline 1980 & 7,808 & 3.2 \\
\hline 1981 & 8,364 & 3.4 \\
\hline 1982 & 9,150 & 3.2 \\
\hline 1983 & 10,791 & 3.6 \\
\hline 1984 & 10,841 & 3.4 \\
\hline 1985 & 12,775 & 3.7 \\
\hline 1986 & 14,236 & 3.8 \\
\hline 1987 & 15,400 & 4.0 \\
\hline 1988 & 16,900 & 4.3 \\
\hline 1989 & 18,000 & 4.4 \\
\hline 1990 & 17,533 & 4.4 \\
\hline 1991 & 18,900 & 4.8 \\
\hline 1992 & 19,400 & 4.9 \\
\hline 1993 & 19,000 & 4.9 \\
\hline 1994 & 21,000 & 5.3 \\
\hline S06re & & 100 \\
\hline
\end{tabular}

Source: State Education Commission, Minority Education Dep' $t$; Guo Sheng, et al. (1989), p. 300; Liu Yingjie (1993), pp. 1546, 2055; Zhongguo shehui tongji ziliao, 1993, pp. 146, 170, 179, 182. 


\section{Appendix C: Minority Cadres in China}

\begin{tabular}{||l|l|l|}
\hline Year & Number of Cadres & Percentage \\
\hline 1950 & 10,000 & \\
\hline 1958 & 400,000 & \\
\hline 1978 & 790,000 & \\
\hline 1980 & & less than $3 \%$ \\
\hline 1982 & $1,030,000$ & $4.8 \%$ \\
\hline 1983 & $1,300,000$ & \\
\hline 1985 & $1,300,000$ & \\
\hline 1986 & $1,370,000$ & \\
\hline 1988 & & $6.1 \%$ \\
\hline 1989 & $1,840,000$ & \\
\hline 1990 & $2,060,000$ & $6.2 \%$ or $6.6 \%$ \\
\hline 1993 & $2,280,000$ & $6.7 \%$ or $7.1 \%$ \\
\hline 1994 & $2,400,000$ & $7.1 \%$ \\
\hline 1996 & $2,480,000$ & $7.1 \%$ \\
\hline
\end{tabular}

Sources: Amat, 1991, 199?; Xinhuc, September 14, 1996; December 12, 1995: July 23, 1994; June 16, 1993; October 5, 1991; November 9, 1989b; May 14. 1986; December 7, 1985; Septembe-16, 1983; August 24, 1982; Renmin Ribao. February 4, 1980; Ma Yin, 1989:33: Hua, 1990:97; Tam \& Wu, 1988:86; Minzli Tuanjie, 1991, p. 4.

\section{Appendix D: Minority Cadres in Xinjiang}

\begin{tabular}{||l|l|l|}
\hline Year & Number of Cadres & Percentage \\
\hline 1955 & 40,000 & \\
\hline 1980 & 120,000 & \\
\hline 1981 & 140,000 & \\
\hline 1982 & 158,800 & \\
\hline
\end{tabular}




\begin{tabular}{|l|l|l||}
\hline 1983 & & $44.4 \%$ \\
\hline 1984 & 182,000 & $43 \%$ \\
\hline 1990 & 240,000 & $46 \%$ \\
\hline 1992 & 264,000 & $46 \%$ \\
\hline 1994 & 270,000 & $46 \%$ \\
\hline
\end{tabular}

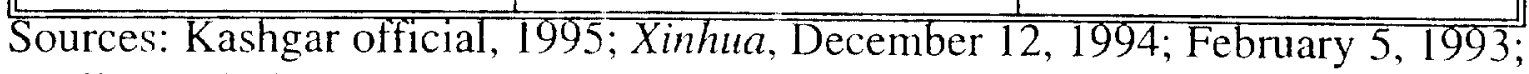
April 24, 1990; February 24, 1984; August 29, 1983; August 16, 1982; July 10, 1981; February 19, 1980.

Appendix E: Minority Representation in NPC's

\begin{tabular}{||l|l|l|l||}
\hline Congress+Year & Total reps. & Min. Reps. & Percentage \\
\hline 1st 1954 & 1,226 & 178 & $14.5 \%$ \\
\hline 2nd 1959 & 1,226 & 179 & $14.6 \%$ \\
\hline 3rd 1964 & 3,040 & 372 & $12.2 \%$ \\
\hline 4th 1975 & 2,885 & 270 & $9.4 \%$ \\
\hline 5th 1978 & 3,497 & 381 & $10.9 \%$ \\
\hline 6th 1983 & 2,978 & 403 & $13.5 \%$ \\
\hline 7th 1988 & 2,978 & 445 & $14.9 \%$ \\
\hline 8th 1993 & 2,980 & 439 & $14.7 \%$ \\
\hline Sourc
\end{tabular}

Source: Adapted from Zhongg minzu tongji nianjian (1994):417; Xinhua, March 3, 1996.

Appendix F: Minority Representation in CPPCC's

\begin{tabular}{||l|l|l|l||}
\hline Conf. + Year & Total Reps. & Minor. Reps. & Percentage \\
\hline 1st 1949 & 198 & 19 & $9.6 \%$ \\
\hline 2d 1954 & 729 & 61 & $8.4 \%$ \\
\hline 3d 1959 & 1,071 & 78 & $7.3 \%$ \\
\hline 4th 1965 & 1,199 & 81 & $6.8 \%$ \\
\hline 5th 1978 & 1,988 & 143 & $7.2 \%$ \\
\hline 6th 1983 & 2,039 & 185 & $9.1 \%$ \\
\hline
\end{tabular}




\begin{tabular}{|l|l|l|l||}
\hline 7 th 1988 & 2,083 & 225 & $10.8 \%$ \\
\hline 8 th 1993 & 2,093 & 241 & $11.5 \%$ \\
\hline
\end{tabular}

Source: Zhongguo minzu tongji nianjian (1994):417

Appendix G: Minority Representation in CCPCC's

\begin{tabular}{||l|l|}
\hline Central Committee & Percentage \\
\hline 8 th 1956 & 5.2 \\
\hline 9 th 1969 & 4.6 \\
\hline 10 th 1973 & 5.6 \\
\hline 11 th 1977 & 5.7 \\
\hline 12 th 1982 & 8.0 \\
\hline 13 th 1987 & 11.2 \\
\hline 14 th 1992 & 10.3 \\
\hline
\end{tabular}

Source: Zang Xiaowei, "The 14th Central Committee of the CCP: Technocracy or Political Technocracy?" Asian Sirvey 33:8 (August, 1993), pp. 787-803. 


\section{Sources}

Agence France Presse (January 23, 1995), "China's urban women prefer one, no children."

Agence France Presse (May 12, 1997), "Xinjiang government dismisses separatist threat."

Agence France Presse (May 13, 1997) "Xinjiang Uighurs bitter at invasion of Chinese immigrants."

Ahmed, Hasan (1992), Preferential policies and educational attainment: a comparative study of India and the United States (unpub'd M.S. thesis, Iowa State University).

Agence France Presse (January 3, 1996), "China free of ethnic rivalry, government says."

Amat, Ismail (1991), "Guanyu fazhan minzu jiaoyu de ruogan wenti," (Certain issues in developing minority education ), Minzu yanjiu, no. 3, May 10, pp. 2443.

Amat, Ismail (1992), "Growing role of minority cadres," China Today, 41, no. 7 (July 7), pp. 13-14.

Amat, Ismail (1994), Head of the State Ethnic Affairs Commission (guojia minzu weiyuanhui), interview, Hong Kong, November 26.

Anderson, Barbara and Brian Silver (1995), "Ethnic differences in fertility and sex ratios at birth in China: evidence from Xinjiang," Population Studies, 49, pp. 211-226.

Ao Junde (1991), "Minzu wenti zai wo guo xin shiqi falu zhongyao diwei," (The Important position of ethnic issues in our country's new legal era), Minzu yanjiu, no. 1, pp. 3-8.

Ba Jiankun (1989), "Xinjiang wei wu er zizhiqu jiaoyu" (Minority education in Xinjiang Uygur Autonomous Region), Zhongguo jiaoyu nianjian, 1988 (Beijing: Zhongguo baike quan shu chubanshe).

Banister, Judith and Christina Harbaugh (1994), C'nina's family planning 
program: inputs and outcomes (Washington: Center for International Research).

Barnett, A. Doak (1993), China's far west: four decades of change (Boulder: Westview).

Becqelin, Nicholas (1997), "Trouble on the marches," China Perspectives no. 10 (March/April), pp. 19-28.

Bjorn, Henrik (1994), "Ethnicity and the local response to state minority policies: from fieldwork in a Dong nationality village in the southern Chinese province of Guangxi," in H. Bjorn, Asian minorities: three papers on minorities in Thailand and China Copenhagen: Center for East and Southeast Asian Studies).

Borchigud, Wurlig (1994), "The impact of urban ethnic education on modern Mongolian ethnicity, 1949-1966," in Stevan Harrell, ed., Cultural encounters on China's ethnic frontiers (Seattle: University of Washington Press), pp. 278-300.

Brugger, Bill and Stephen Reglat (1994), Politics, Economy and Society in Contemporary China (Stanford: Stanford University).

Centre for Development Studies (1992), Affirmative action in the new South Africa: the apartheid legacy and comparative international experience and mechanism of enforcement (Capetown: University of the Western Cape).

Chan, V. (1996)), "Delegates from poorer provinces receive Jiang help," South China Morning Post, March 7, p. 6.

Chen Hongtao (1990), Zhongguo minzu jiaoyu fazhan tujing tantao (An inquiry into the way for China's minority education to develop) (Beijing: Zhongyang minzu xueyuan chubanshe).

Chen Kuiyuan (1991), "Study the Marxist nationality theory and currectly understand the nationality isssues of the new period," Shijian (Time) (Hohhot). No. 10, pp. 4-17, in Joint Publications Research Service (JPRS)-CAR-92-021 (April 16, 1992), pp. 1-11.

Chen Ming (1989), "China population frustrates way to prosperity," Inter Press Service, March 16.

Chen, K., "Muslims in China hate Beijing a bit less," Christian Science Monitor. 
October 21, 1994, p. 10.

Cheung, A. (1995), "Aid 'essential' for Xinjiang's stability," South China Morning Post, September 21, p. 8.

Cherrington, R. (1990), "In danager of provoking a token resistance," Times Educational Supplement, October 19, p. 17.

Conly, Shanti and Sharon Camp (1992), China's family planning program: challenging the myths (Washington: Population Crisis Committee).

Cooney, Rosemary and Li Jiali (1995), "Household registration type and compliance with the 'One Child' policy in China, 1979-1988," Demography, 31, no. 1 (February), pp. 21-32.

Crothall, G. (March 23, 1993), "Options for staff affected by cuts," South China Morning Post, p. 11.

Daniels, Douglas (1984), "Affirmative action in education in Inner Mongolia, People's Republic of China," Canadian Journal of Native Education, 11, no. 2 (1984), pp. 14-26.

Davis, Anthony (1997), "Beijing should have seen Uighur problem coming," Asia Times, March 21, pp. 9-14.

Deanne, D. (1992), "The little emperors," Los Angeles Times, July 26, p. 16.

deVries, Sijera and Thomas Pettigrew (1994), "A comparative perspective on affirmative action: Positieve aktie in the Netherlands," Basic and Applied Social Psychology, 15, no. 1-2, pp. 179-199.

Dixit, K. (May 8, 1990), "China prefers stick to the carrot to curb ethnic unrest," Inter Press Service.

Dowdle, Michael (1996), "Realizing constitutional potential: the Chinese legislature begins to exercise its full authority," China Business Review 23, no. 6. pp. 30-37.

Dreyer, June (1993), "Ethnic minorities in Mainland China under Teng Hsiaop "ing," in Bih-jaw Lin and James T. Myers, Forces for change in contemporary China (Columbia: University of South (arolina), pp. 251-261. 
Dreyer, June (1994), "The PLA and regionalism in Xinjiang," Pacific Review, 7, no. 1, pp. $41-56$.

Du Jixun (1993), "On the benefits of family planning," Xinjiang Ribao, April 27, p. 6 in JPRS-CAR-93-049 (July 14), pp. 36-37.

Eastland, Terry (1996), Ending affimative action (New York: New Republic Books).

ENR (Engineering News Reports) (March 17, 1997), "Study says minority ownership is not a factor in performance," p. 17.

Faison, S. (1997), "Chinese happily break the 'one child' rule," New York Times, August 17, p. 1.

Faundez, Julio (1994), Affirmative action: international perspectives (Geneva: International Labour Organization).

Feigon, Lee (1996), Demystifying Tibet: Unlocking the secrets of the land of snow (Chicago: Ivan Dee).

Ferdinand, Peter (1994), "Xianjiang: relations with China and abroad," in David Goodman, ed., China deconstructs: Politics, trade and regionalism (London: Routledge), pp. $271-285$.

Fraser, D. (1986), "Chinese students stage new protest in Xinjiang," Reuters, January 1.

Gittelman, Zvi (1990), "The politics of ethnicity and affimative action in the Soviet Union," in Wyzan (1990), pp. 167-195.

Gladney, Dru (1991), Muslim Chinese: ethnic nationalism in the People's Republic of China (Cambridge, Harvard).

Gladney, Dru (1995), "Economy and ethnicity: the revitalization of a Muslim minority in southeastern China," in Andrew Walder, ed., The waning of the Communist state: Economic origins of political decline in China and Hungary (Berkeley: University of California), pp. 242-266.

Gu Qingzhong and Zou Fengcai (1993), "Zhongguo chaoxianzu renkou fazhan yushi he tezheng," (Tendencies and characteristics of the development of 
China's ethnic Korean population), Renkou Xuekan, no. 3 (June), pp. 41-43.

Guo Sheng, et al. (1989), Xin zhongguo jiaoyu sishi nian (Forty years of education in New China) (Fuzhou: Fujian jiaoyu chubanshe).

Guldin, Gregory (1991), "The organization of minority studies in China," China Exchange News, 19, no. 2 (Summer), pp. 7-12.

Hannum, Emily and Yu Xie (1995), Ethnic and gender stratification in an economic reform era: the case of Xinjiang (Ann Arbor: University of Michigan Population Studies Center).

Harrell, Stevan (1993), "Linguistics and hegemony in China," International Joumal of the Sociology of Language," 103, pp. 97-114.

Hasi Bagen (1995), "Wo guo shaoshu minzu gaodeng jiaoyu xianzhuang yu zhanwang," (The present situation and prospects for China's minority higher education), Minzu gaodeng jianyu, no. 2., pp. 62-67.

He Jiangcheng (1990), "China's policy on nationalities," in Dae-sook Suh and Edward Schultz, eds., Koreans in China (Honolulu: University of Hawaii, Center for Korean Studies), pp. 1-30.

He Pin (1991), "Why do rebellions occur so frequently in Xinjiang," Nan Pei Chi (Hong Kong), November/December 1991, in JPRS-CAR-92-011 (March 6, 1992), pp. 1-10.

Heberer, Thomas (1989), China and its national minorities: autonomy or assimilation (Armonk: ME Sharpe).

Holley, D. (1990), "China applies family limits to minorities," Los Angeles Times, November 17, p. A3.

Holzer, Harry and David Neumark (1996), Are affirmative action hires less qualified? (Cambridge: National Bureau of Economic Research), Working Paper Series No. 5603.

Hong Kong Standard (1989), [Untitled], February 22, 1989, p. 12.

Hsieh Jiann (1994), Haixia liang an renkou xianxiang de fenxi guoji xueshu yan tao hui: shi lun zhonggong dui shaoshu minzu de renkou zhengce (International 
academic research symposium on the analysis of the cross-straits population phenomenon: tentative theses on the Chinese Communist population policy for ethnic minorities) (Taipei: United Board for Christian Higher Education in China).

Hu Angang (1994), "Survey: Most nationalities affairs cadres believe problems to worsen," Lien Ho Pao (Hong Kong), November 7, p. 7, in BBC/SWB, November 30, 1994, FE/2166/G.

Hua Juxian (1990), "China emphasizes cultivating minority nationality cadres," Liclowang (overseas edition), no 51, December 17, 1990, pp. 14-15 in JPRSCAR-91-022 (April 24, 1991), pp. 96-97.

Hua Juxian (1992), "Population of ethnic minorities in China increases rapidly," Lialowang (overseas edition) no. 9 (March 2) in JPRS-CAR-92-049 (July 14. 1992), pp. 45-47.

Huang Gongxue (1993), Dangdai zhongguo minzu renwu (Contemporary tasks of China's minorities) (Beijing: Dangdai Zhongguo).

International Committee for Tibet (1994), "Hunger and poverty said to be on the rise: Tibetan deputies dispute claims of improved conditions," World Tibet Network, December 19.

Jiao Shuqian, "Wo guo minzu diqu quyu fanwei chuyi" (A tentative discussion of the scope of China's minority areas), Zhongnan minzu xueyuan xuebao, no. 2 (1996), pp. 54-57.

Johnson, I. (March 4, 1995), "Chinese congress sheds rubber-stamp reputation," The Sun (Baltimore), p. $3 \mathrm{~A}$.

Johnson, I. (May 31, 1995), "China's simmering 'internal colony," The Sum (Baltimore), p. $1 \mathrm{~A}$.

Karklins, Rasma (1986), Ethnic relations in the USSR (Winchester, Mass: Unwin, Hyman).

Kashgar Official (1995), interview at the Prefectural Ethnic Affairs Commission. Ethnic and Religious Office (zhou minwei de minzu zongjiaochu), Kashgar. Xinjiang, July 7, 1995. 
Kormondy, Edward (1995), "Observations on minority education, cultural preservation and economic development in China," Compare, 25, no. 2, pp. 161178.

Kostrzewa, Thomas (1996), Separatist nationalism in Xinjiang (Unpub'd Ph.D. diss., University of Notre Dame).

Kristof. N. (1991), "Affirmative action Chinese style makes some progress," New York Times, March 31, p. E4.

Kumar, Mitra Subrata (1991), The politics of positive discrimination: a crossnational perspective (London: Sangam).

Kwan, D. (1995), "Mao's philosophy set to stay on curriculum," South China Morning Post, December 22, 1995, p. 9.

Kwong, Julia and Hong Xiao (1989), "Educational equality among China's minorities," Comparative Education, 25. no. 2, pp. 199-243.

Kynge, J. (1990), "China to boost birth controls before expected baby boom," Reuters, April 13, 1990.

Lam, W. (1993), "Han 'moderate' replaced in Tibetan reshuffle," South China Morning Post, June 7, p. 7.

Lam, W. (1994), "Beijing steps up official job swaps," South China Morning Post, June 23, p. 13.

Lam, W. (1995), "Officials from central and western regions have been unable to halt the drain of professionals and intellectuals to the rich coast," South China Morning Post, March 30, p. 9.

Lam, W. (1996), "Regional conflicts financial flashpoint," South China Morning Post, March 6, p. 10.

Lam, W. (1997), "'Young Tutks' to the fore in congress vote," South China Morning Post, August 25, p. 9

Lamontagne, Jacques (1992). "Improving the education of China's national minorities," in Douglas Ray \& Deo Poonwassie, Education and cultural differences: new perspectives (New York: Garland), pp. 183-209. 
Li Fang (1993), "Xinjiang jingji he shehui fazhande jige wenti," Minzu yanjiu, no. 2, pp. 17-18.

Li Ze (1995), Director of the Institute of Ethnic Studies, Xinjiang Academy of Social Sciences (Xinjiang shehui kexue yuan, minzu yanjiusuo), interview, Urumqi, June 27, 1995.

Liu Yingjie (1993), ed., Zhongguo jiaoyu da shidian, 1949-1990 (Hangzhou: Zhongguo jiaoyu chuban she).

Lo, J.P. (1961), "Five years of the Sinkiang-Uighur Autonomous Region," China Quarterly, no. 8 (October-December), pp. 92-105.

Lofstedt, Jan-Ingvar (1987), "Education for national minorities in China: an overview," Journal of Negro Education, 36, no. 3, pp. 326-337.

Lovell, G. (1981), "Disco dancing makes discreet appearances at the University of Inner Mongolia," Reuters, June 24, 1981.

Lu Hui (1992), Reform in minority areas (Beijing: New Star).

Lu Yumin (1994), State Minority Affairs Commission (guojia minzu weiyuanhui), Education Department deputy office chief (jiaoyu ting fuzhuren), interview, Beijing, June 30.

Luo Cun (1997), "Lun zhongguo shaoshu minzu renkou de shengyu zhengce" (On China's minority population family planning), Minzu yanjiu no. 2, pp. 49 58

Mit Maozong and Li Yuan (1992), "Proposals for speeding up economic development in areas inhabited by minority nationalities -- jottings on studying the spirit of the central nationalities work conference," Jingji guanli, no. 7 (July), pp. 13-17 in JPRS-CAR-92-087, pp. 6-11.

Ma Yin (1989), China's minority nationalities (Beijing; Foreign Language Press).

Mackerras, Colin (1994), China's minorities: integration and modernization in the twentieth century (Hong Kong: Oxford).

Mao Gongning (1992), "Guanyu woguo minzu gongzuo jiben jingyan de tantao" 
(An inquiry into the fundamental experiences of China's ethnic work), Zhongyang minzu xueyuan xuebao, 1, pp. 3-11.

Ministry of Education (1984), Zhongguo jiaoyu chengjiu, 1949-1983 (Achievements of education in China, 1949-1983) (Beijing: People's Education Press).

Minzu Tuanjie (1991), "Qieshi gaohao shaoshu minzu diqu dang de jianshe -qingzhu zhongguo gongchandang chengli qishi zhounian" (Conscientiously build the ethnic minority areas -- celebrate the 70th anniversary of the founding of the Communist Party of China), no. 7, November 10, pp. 3-4.

Ng, Elizabeth (1991), Preferential policies and political stability in developing plural polities (Windsor: University of Windsor, unpub'd M.A. thesis).

Nesiah, Devanason (1997), Discriination without reason? preferential policies in the USA, India and Malaysia (Delhi: Oxford University Press, 1997).

Ngapoi Ngawang Jigme (1984), "Explanation of minority nationalities law," Renmin Ribao, June 4, in BBC/SWB, June 19, 1984, FE/7673/C/1.

O'Brien, Kevin and Li Lianjiang (1993), "Chinese political reform and the question of 'deputy quality,' China Information, 8, no. 3 (Winter), pp. 20-31.

O'Brien, Kevin (1994), "Agents and remonstrators: role accumulation by Chinese People's Congress Deputies," China Quarterly, No. 138 (June, 1994), pp. $359-380$.

Olivier, Bernard (1993), The implementation of China's nationality policy in the northeastern provinces (San Francisco: Mellen Research University Press, 1993).

Pan Qi (1992), "Minority region spiritual civilization development rises to a new level," Qiu Shi, no. 24, December 16, 1992, pp. 25-28, in JPRS-CAR-93-017 (March 9, 1993), pp. 3-6.

Parikh, Sunita (1997), The politics of preference: democratic institutions and affirmative action in the United States and India (Ann Arbor: University of Michigan).

Peters, William (1991), "Central Asia and the minority question," Joumal of the Royal Society for Asian Affairs. 32, pp. 152-157. 
Postiglione, Gerard (1992), "China's national minorities and educational change," Journal of Contemporary Asia, 22, no. 1, pp. 20-44.

Postiglione, Gerard (1995), "Basic education and school discontinuation in national minority border regions of China," in G. Postiglione and Lee Wing On, ed., Social change and educational development: Mainland China, Taiv'an and Hong Kong (Hong Kong: Centre for Asian Studies), pp. 186-206.

Poston, Dudley and Jing Shu (1987), "The demographic and socioeconomic composition of China's ethnic minorities," Population and Development Review, 13, pp. 703-722.

Preston, Y. (1992), "China’s shadow population," Straits Times, June 21, p. 1.

Pyong Gap Min (1990), "A comparison of the Korean minorities in China and Japan," International Migration Review, 26, no. 1 (1990), pp. 4-21.

Qiu Pu (1989), "On the trend of the development of the relations among the nationalities in China," in Chien Chiao and Nicholas Tapp, ed., Ethnicity and Ethnic Groups in China (Hong Kong: Chinese University, New Asia College), pp. 33-40.

Renmin Ribao, February 4, 1980, 'Training minority-nationality cadres is an important task," in BBC/SWB, February 19, 1980, FE/6349/BII/8.

Renmin Ribao, June 4, 1984, "Regional autonomy law for minority nationalities of China," in FBIS-CHI-84-116 (June 14, 1984, pp. K3-K10.

Reuters (June 28, 1988), "China asks Muslim clergy to promote new birth control rules."

Reuters (April 25, 1993), "China's Moslem minority left behind in oil rush."

Reuters (October 25, 1995,, "Sixty percent of China HIV carriers under 30."

Reuters (March 14, 1997), "China parliament in rare protest vote over crime."

Reuters (March 19, 1997), "China Moslem region resists relocation plan."

Rockefeller Foundation (1984), International Perspectives on Affirmative Action (New York: Rockefeller Foundation). 
Rong Shen (1995), vice-director of the Inner Mongolian Ethnic Affairs Commission, interview in Hohhot, April 13, 1995.

Rossett, Arthur (1991), "Legal structures for special treatment of minorities in the People's Republic of China," Notre Dame Law Review, 66, no. 5, pp. 1503 1529.

Sautman, Barry (1997a), "Expanding access to higher education for China's national minorities: policies of preferential admissions," in Gerard Postiglione and Reggie Stites, eds., The education of China's national minorities (New York: Garland).

Sautman, Barry (1997b), "Myths of descent, racial nationalism and ethnic minorities in the PRC," in Frank Dikotter, ed., Constructing Racial identities in China and Japan (London: Hurst).

Schwarz, Henry (1963), "Chinese migration to northwest China and Inner Mongolia, 1949-1959," China Quarterly, no. 16 (November-December), pp. 62 74.

Singer, R. (1997), "China's minorities get huge affirmative action benefits," Seattle Times, August 26:1.

Song Hanliang (December 1 1, 1993), "Work hard to do a good job in Xinjiang's stability and development," Xiniiang Ribao, pp. 1-2, in $B B C / S W B$, January 4 , 1994, FE/1886/G.

Sowell, 'Thomas (1990), Preferential polic ies: an international perspective (New York: William Morrow).

Sun, L. (1990), "Ancient silk road oasis restive," Washington Post, September 25 , p. A 13.

Tam, Siu-Mi and David Y.H. Wu (1988), "Minorities policy in the People's Republic of China: Its implications in Southeast Asia," Southeast Asian Journal of Social Science, 16, no. 2, pp. 78-95.

Tan Tarn How (March 4, 1995), "Greater feedback role for advisory body," Straits Times, p. 16.

Tan Tarn How (March 29, 1995)), "Political change in China moves slowly but 
surely," Straits Times, p. 28.

Turpan cadre (1995), interview in Turpan, July 1, 1995.

Turpan official (1995), Turpan Prefecture, Xinjiang, interview in Turpan, July 2.

Tyler, P. (1995), "Chinese leader says 'mistakes' by government fueled inflation," New York Times, March 5, p. Al.

Wang Jianmin (1995), professor, Central Nationalities University, interview, June 12, 1995.

Wei Xiang (1990), "Unity among nationalities is an important factor for stability in China," Zhongguo Xinwenshe, February 17, 1990 in FBIS-CHI-90-038, February 26, 1990, pp. 20-21.

Weiner, Myron (1983), "Political consequences of preferential policies: a comparative perspective," Comparative Politics, 16, pp. 35-51.

Weiner, Myron (1993), ed., "Affirmative action in India, Malaysia, Sri Lanka and the USA," Development \& Democracy no. 6, pp.

Wong, J. (1994), "Quota crazy," Rocky Mountain News, April 18, p. 26 A.

Wren, C. (1983), "China's policies on the size of families is extended to include minorities," New York Time's, February 10, p. Al6.

Wu, David Y.H. (1990), "Chinese minority policy and the meaning of minority culture: the example of the Bai in Yunnan, China," Human Organization, 49, no. 1, pp. $1-12$.

Wu Heng and Long Pingping (1985), "Lun tigao shaoshu minzu wenhua jiaoyu shuiping zai shoudu minzu gongzuo zhong de diwei" (On the place of raising the cultural and educational levels of ethnic minorities in ethnic minority work in the capital), Minzu lilun yanjiu tongxun, 1, (May 25, 1985), pp. 52-59.

Wu Zongjing (1992), "Lun wo guo minzu guanxi fazhi tedian" (On the special characteristics of the legal system with regard to our country's ethnic relations), Minzu yanjiu, no. 1, pp. 8-14. 
Wynan, Michael (1990), The political economy of ethnic discrimination and affirmative action: a comparative perspective (New York: Praeger).

Xinhua (December 4, 1979), "Attention should be paid to training more talented people of minority nationality," in $B B C / S W B$, December 14, 1979 , FE/6297/BII/11.

Xinhua (February 6, 1980). "Xinjiang nationality cadres," in $B B C / S W B$, February 19, 1980), FE/6349/BII/11.

Xinhua (October 28, 1980), "More minority undergraduates in China," Item no. 102807.

Xinhua (January 1, 1981), "Xinjiang adds articles to new marriage law," Item no. 010107.

Xinhua (February 16, 1981), "National conference on minority education," in $B B C / S W B$, March 4, 1981, FE/6664/BII/l.

Xinhua (July 10, 1981), "Xinjiang promotes local cadres," Item no. 071023.

Xinhua (August 16, 1982), "Xinjiang leader calls for strengthening of unity among various nationalities," Item no. 081603.

Xinhua (August 24, 1982), "China's minority areas make great achievements," Item no. 082417.

Xinhua (October 27, 1982), "Other points on the census," in $B B C / S W B$, October 28, 1982), $\mathrm{FE} / 7168 / \mathrm{C} / 4$.

Xinhua (December 4, 1982), "Full text of the Constitution," in $B B C / S W B$, December 6, 1982, FE/7201/C/1.

Xinhua (August 29, 1983), "More minority cadres promoted in Xinjiang," Item no. 082923.

Xinhua (September 16, 1983), "Minority cadres grow up rapidly," Item no. 0091653.

Xinhua (February 24, 1984), "Xinjiang elects new party committee," Item no. 022410 . 
Xinhua (July 24, 1985), [untitled], Item no. 072448.

Xinhua (December 7, 1985), [untitled], Item no. 120786.

Xinhua (February 7, 1986), [untitled|, Item no. 020773.

Xinhua (May 14, 1986), "Reforms spur development in minority areas," Itern no. 00514065 .

Xinhua (December 4, 1986), "The 'one-child policy' and small ethnic groups," in $B B C / S W B$, December 19, 1986, FE/8446/BIU/1.

Xinhua (June 29, 1987), "Deng Xiaoping meets former US president," Item no. 0629084 .

Xinhua (November 9, 1989a), "Minority education thrives in Xinjiang," Item no. 1109138.

Xinhua (November 9, 1989b), "Minority cadres give good performance," Item no. 1109028 .

Xinhua (November 23, 1989), "China develops minority nationality preparatory courses," Item no. 1123065.

Xinhua (April 24, 1990), "Regional autonomy law benefits minorities," Item no. 116183.

Xinhua (May 12, 1991), "Population increase of northwest minorities," Item no. 0512124 .

Xinhua (June 5, 1991), "Quality of party members improves," in $B B C / S W B$, June 7, 1991, FE/10092/B2/1.

Xinhua (August 15, 1991), "Xinjians stresses education for ethnic minorities," Item no. 0815044.

Xinhlua (September 29, 1991), "Ethnic regions experience rapid economic and social development," Item no. 00929117.

Xinhua (October 5, 1991), "Ethnic mninority cadres number over two million," in $B B C / S W B$, October 8, 1991, FE/1 197/B2/1. 
Xinhua (November 11, 1991), "Xinjiang develops higher education for ethnic minorities," Item no. 1111072.

Xinhua (January 12, 1992), "State Councıl issues circular on minority autonomy law (1)," Item no. 0112091.

Xinhua (January 20, 1992), More thnic minority students receive education in Xinjiang," Item no. 01200097.

Xinhua (February 1, 1992), "Minority population still grows," Item no. 0201080.

Xinhua (August 5, 1992), "Ethnic minorities more aware of birth control," Item no. 080512 .

Xinhua (December 16, 1992), "Ethnics opt to have fewer kids to boost wealth," Item no. 1216089.

Xinhuta (February 5, 1993), "Stresses training of minority leaders," Item no. 0205171 .

Xinhua (March 13, 1993), "More developed eastern areas help Xinjiang economy," Item no. 0313116.

Xinhua (March 29, 1993), "Name list of NPC Nationalities Committee," in $B B C / S W B$, April 1, 1993, FE/1652/Cl.

Xinhua (June 6, 1993), "Xinlua gives statistics for minority cadres," in $B B C / S W B$, June $16,1993, \mathrm{FE} / 1716 / \mathrm{B} 2$.

Xinhua (August 25, 1993), "Seventh national congress of women to open," Item no. 0825063 .

Xinhua (October 22, 1993), "Regulations on ethnic township administration," in $B B C / S W B$, November 9, 1993, FE/1841/S1.

Xinhua (October 22 1993). "Regulations on work with urban national minorities" (1993), in BBC/SWB, November 9, 1993, FE/1841/S1.

Xinhua (May 28, 1994), "Ethnic education," Item no. 0528130.

Xinhua (July 10, 1994), "Xinjiang boosts education for ethnic minorities," in 
FBIS-CHI-94-133 (July 12, 1994), p. 86.

Xinhua (July 23, 1994), "China develops minority nationality regions," Item no. 00723117.

Xinhua (September 8, 1994), "Forum on national unity: Li Ruihuan tells forum minority areas must exploit their natural resources," in $B B C / S W B$, September 28 , 1994, FE/2112/G.

Xinhua (September 23, 1994), "Efforts urged to step up training of officials of national minorities," Item no. 0923182.

Xinhua (October 3, 1994), "Xinjiang stresses development of education of ethnic groups," Item no. 1003142.

Xinhua (December 10, 1994), "Policy favors minorities to favor to foster education," Item no. 1210049.

Xinhua (December 12, 1994), "Numbers of ethnic cadres grow in minority regions," in $B B C / S W B$, December 15, 1994, FE/2179/G.

Xinhua (February 25 1995), "Electoral law for National People's Congress, local congresses," in BBC/SWB. April 1, 1995, FE/2267/S2.

Xinhua (April 26, 1995). "China 10 commend some 3,000 national model workers," Item no. 0426040.

Xinhua (June 29, 1995), "CPC growing, members better educated," Item no. 0629241 .

Xinhua (July 28, 1995), "China to tra:n more professionals for border area," Item no. 0728128 .

Xinhua (September 23, 1995), 'Northwest provinces hold meeting on nationalities affairs," in $B B C / S W B$, September 27, 1995, EE/2419/G.

Xinhua (September 24, 1995), "Xinjiang leader on 40th anniversary" development," in BBC/SWR, September 27, 1995, EE/D2419/G.

Xinhua (November 17, 1995), "China Improving ethnic education," Itern no. 1117133. 
Xinhua (November 21, 1995), "China to improve ethnic education," Item no. 1121097 .

Xinhua (December 12, 1995), "Survey cites 'splendid results' in promoting ethnic work," in $B B C / S W B$, December 21, 1995, EE/D2493/S1.

Xinhua (December 27, 1995), "White Paper: Human Rights Progress in China," Item no. 1227204.

Xinhua (January 14, 1996), "Educational help offered to poor areas," Item no. 0114098.

Xinhua (February 14, 1996), 'Census: China's population growth slowing down," Item no. 0214167.

Xinhua (February 27, 1996), "CPPCC plays stronger supervisory role," in $B B C / S W B$, February 28, 1996, EE/D2548/G.

Xinhua (March 3, 1996), "Vice Chairman: Legal system ensures overall development in ethnic-minority areas," Item no. 0303050.

Xinhua (June 13, 1996), "CPC has 57 million members," Item no. 0613198.

Xinhua (June 17, 1996), "China develops pre-college education system for ethnic groups," Item no. 0617108.

Xinhua (March 5, 1997), "CPPCC official urges religious figures to safeguard stability," in $B B C / S W B$, March 7, 1997, FE/D2861/S1.

Xinhua (March 8, 1997), "Ethnic minority areas' economic growth higher than national average," Item no. 0308134.

Xinhua (March 18, 1997), "Beijing plans investment in ethnic minority areas," FBIS-CHI-97-078.

Xinhua (March 26, 1997), "Spokesman says report alleging exploitation of Xinjiang 'groundless'," in BBC/SWB, March 28, 1997, FE/D2879/G.

Xinhua (April 24, 1997), "Equality among nationalities ensures stability in Inner Mongolia," Item no. 0424179. 
Xinhua (May 6, 1997), "Chinese parlıament discusses election of new deputies," in $B B C / S W B$, May 8, 1997, FE/D2913/G.

Xinjiang Han student (1995), interview in Berkeley, California, USA, March 27, 1995.

Xinjiang jiaowei (Education Ministry) (1995), interview with official in Urumuqi, June 28, 1995.

Xinjiang minwei (Ethnic Affairs Commission) (1995), interview the Deputy Director (fu zhuren) in Urumqi, June 30, 1995.

Xinjiang Ribao (April 9, 1993), "Xinjiang minority policy hurt by 'equal competition," in JPRS-CAR-93-053 July 26, 1993.

Xinjiang Ribao (March 14, 1997), "Xinjiang statistical communique for 1996," in $B B C / S W B$, May 7, 1997, FE/W0485/WS2.

Xinjiang TV (May 10, 1994), "Xinjiang commends outstanding radio, TV stations," in $B B C / S W B$, May 24, 1994, FE/2005/G.

Yang Zheng (1995), Professor at Xinjiang University, interview in Urumqi, June 29).

Yang Chunpu (1994), "Wo guo shaoshu minzu wenhua shuiping da fudu tigao" (Our country's minority cultural level is being raised to a great extent), Minzu no. 6 (1994), pp. 40-41.

Yang Zheng (1995), population specıalist, interview at Xinjiang University, July 1.

Yao Zhongwu (1992), "An exploration of problems in selecting and training minority nationality reserve cadres," Lingdao kexue, no. 1, pp. 114-115, in JPRS-CAR-92-030, May 15, 1992, pp. 1-3.

Yasheng Tuerxun (1990), "Family planning -- beneficial to nation, family and people," Xinjiang Ribao, July 11, 1990, p. 2 in JPRS-CAR-90-089, November 30, 1990, pp. 34-36.

Ye Zhaoyang (1994), "Colleges enrolling students throughout the country should set a unified test score requirement and practice unified admissions," Higher 
Education Front, no. 10, pp. 13-14.

Yuan Qing-li (1990), "Population Changes in the Xinjiang Uighur Autonomous Region (1949-1990)," Central Asian Survey, 9, no. 1, pp. 49-73.

Yuan Xin (1994), "Weiwuerzu renkou wenti zhonghe yanjiu" (A synthesis of research on questions of the Uygur population), Xinjiang daxue xuebao, 22, no. 4 , pp. $1 \cdots 19$.

Zeng Zhaohua (1992), "Dui minzu jiaoyu zhengce de youhuixing renshi" (Knowing the preferential nature of minority education policy), Zhongguo minzu jiaoyu, no. 3, pp. 67-69.

Zhang Huijun (1996), "Minzu diqu jingji fazhan chaju de tanxi

(A probing of the gap in minority areas economic development), Yunnan shehui kexue, no. 1, pp. 14-20.

Zhang Lifang (1994), "The source of national harmony," Beijing Review, November 7-13, pp. 9-13.

Zhang Tianlu (1990), "Population growth, family planning in religious minority groups," Renkou yanjiu, November 29, 1990, pp. 16-21, in JPRS-CAR-91-018 (March 29, 1991), pp. 69-75.

Zhang Tianlu (1991), "Bashi niandai yi yilai shaoshu minzu renkou de xin taishi" (The new upsurge in the minority population in the 1980s), Zhongguo shehui kexue, no. 3, pp. 19-35.

Zhang Tianlu (1995), specialist in minority demographics, Beijing Economics College, interview in Beijing, June 22.

Zhang Xia (1994), "Minority groups sometimes outdo Hans," China Daily, November 9,1994 , p. 4.

Zhang Yenming (1991), Effects of policy changes on college enrollment of minority students in China, 1949-1989 (Unpub'd Ed.D. dissertation, Harvard University).

Zhao Shu (1995), Deputy Director of the Beijing Ethnic Affairs Commission (Beijingshi minwei), interview, Beijing, June 23. 
Zhongguo jiaoyu nianjian 1949-1981 (Chinese education yearbook) (1984) (Beijing: Zhongguo baike quanshu chuban she).

Zhongguo minzu tongji nianjian, 1949-1994 (Chinese minorities statistical yearbook)(1994) (Beijing: Minzu chubanshe).

Zhongguo shehui tongji ziliao (Chinese social statistics data) (1993) (Beijing: Zhongguo tongji chubanshe).

Zhongguo xinwen she (September 23, 1993), "Number of minority nationality students increases," in $B B C / S W B$, September 25, 1993, FE/1803/G. 